\title{
Soil organic carbon stocks under different forest types in Pokhare khola sub-watershed: a case study from Dhading district of Nepal
}

\author{
B. M. Pradhan ${ }^{1}$, K. D. Awasthi ${ }^{1}$ \& R. M. Bajracharya ${ }^{2}$ \\ ${ }^{I}$ Department of Forest Products and Engineering, \\ Institute of Forestry, Nepal \\ ${ }^{2}$ Kathmandu University, Nepal
}

\begin{abstract}
Assessment of carbon stock in vegetation and soil is an essential step in estimating the carbon sequestration potential of an ecosystem. This study was carried out to quantify total carbon sequestration in different forest types of the Pokhare Khola sub-watershed (forested area of 312 ha), Dhading, Nepal. The inventory for estimating the above and belowground biomass of different forests was carried out using the stratified random sampling method with $0.5 \%$ sampling intensity for plant biomass. The dry biomass was calculated using allometric models.

Four soil profiles from each forest types were excavated and soil samples were taken from the soil profile up to $1 \mathrm{~m}$ depth at intervals of $20 \mathrm{~cm}$. The soil bulk density was collected using a core ring sampler of $9.5 \mathrm{~cm}$ long and $4.2 \mathrm{~cm}$ diameter and organic carbon content was assessed using the Walkley and Black method. The total soil carbon stock in all forest types was estimated at $42,523 \mathrm{t} / \mathrm{ha}$, Shorea forest $62 \%$, Schima-Castonopsis forest $25 \%$, Pine-Shorea forest $5.5 \%$, and degraded forest $7.5 \%$. The distribution pattern of carbon stock was mainly due to the biomass of the stand, carbon content of soil and area coverage of these forest types. The total biomass carbon in forest was found as $77.68 \mathrm{t} / \mathrm{ha}$ and SOC sequestration $58.6 \mathrm{t} / \mathrm{ha}$.

The study showed that soil organic carbon was higher in the upper layer $(0-$ $20 \mathrm{~cm}$ ) in all forest types and rapidly declined below the $20-40 \mathrm{~cm}$ depth. The rate of SOC concentration is in decline trend as the depth increased. The study revealed that a Shorea forest and Schima-Castonopsis forest are better than a Pine-Shorea forest and degraded forest in carbon stocking.

Keywords: biomass, biomass carbon, bulk density, carbon sequestration, carbon stock, soil organic carbon.
\end{abstract}




\section{Introduction}

Carbon sequestration is the removal of carbon from the atmosphere by storing it in the biosphere. About 2/3 of terrestrial carbon is sequestrated in the standing forest, forest under storey plant, leaf and forest debris, and in forest soils (Sedjo et al. [1]). Forest and wooded areas are natural carbon sinks. This means that trees store carbon by sequestrating atmospheric carbon in the growth of wood biomass through the process of photosynthesis; thereby increasing the soil organic carbon (Brown and Pearcel [2]).

The carbon pool in the terrestrial ecosystem can be broadly categorized into vegetative carbon and soil carbon components. Vegetative carbon can be further categorized into carbon in the aboveground biomass, belowground biomass (Hamburg [3]). These stocks are dynamic, depending upon various factors and processes operating in the system, the most significant being land use and land use changes, soil erosion and deforestation (IPCC [4]).

Forests and wooded areas are large reservoirs of carbon as well as potential natural carbon sinks. Trees store carbon by sequestering atmospheric carbon in the growth of wood biomass through the process of photosynthesis; thereby increasing the soil organic carbon (Brown and Pearcel [2]). Forest carbon sinks are believed to offset a significant proportion of carbon emissions associated with fossil fuel combustion. The surface soil organic carbon pool (SOCP) and turnover time are particularly sensitive to a range of factors such as climate, topography, soil and crop management, and other anthropogenic conditions. This study aims to estimate the aboveground, belowground biomass carbon stock in four forest types and soil organic carbon in four forest types under a different soil profile of Pokhare khola sub-watershed, Dhading district, Nepal.

\section{Materials and methods}

\subsection{Description of study area}

The Pokhare khola sub-watershed $\left(27^{\circ} 46^{\prime} 28^{\prime \prime}-27^{\circ} 48^{\prime} 06^{\prime \prime} \mathrm{N}\right.$ latitude and $84^{\circ} 53^{\prime} 32^{\prime \prime}-84^{\circ} 55^{\prime} 11^{\prime \prime} \mathrm{E}$ longitude) is a middle mountain sub-watershed in Nepal, covering an area of 5.36 (536 ha) square kilometers The Prithvi Highway passes through the lower part of the watershed along Trishuli River and is 65 kilometers west from the capital city, Kathmandu. The area covers part of ward numbers 2 and 3 of Pida VDC. The location map is presented in Figure 1. The watershed terrain lies in the middle mountain ranges.

The watershed consists of moderate to very steep slopes with an altitude ranging from $400 \mathrm{~m}$ to $1079 \mathrm{~m}$ asl. The sub-tropical climate with an of average $8^{\circ}$ and $31^{\circ} \mathrm{C}$ temperature and the average rainfall recorded at Dhading is 1370 $\mathrm{mm}$ and average rainy days in a year is 104 . The predominant soil in the watershed comprises of cambisols followed by luvisols in the lower part of the watershed and leptosols in some of the degraded area. The watershed has mixed sub-tropical vegetation with dense Shorea forest at lower altitude, mixed with other sub-tropical vegetation; pine at middle altitude and temperate broadleaf 


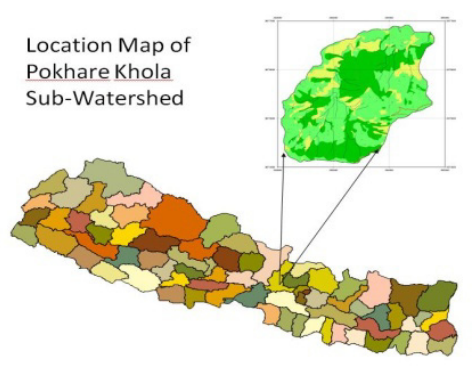

Figure 1: $\quad$ Location map of study area.

forest (Schima-Castanopsis) at higher altitude. Forests can be classified to dense Shorea forest, Pine-Shorea forest, Schima-Castanopsis forest and degraded forest.

\subsection{Data collection}

\subsubsection{Sampling}

Stratified random sampling was used for collecting data for plant biomass. 7 sample plots of $20 \mathrm{~m} \mathrm{x} 25 \mathrm{~m}$ for trees $(>30 \mathrm{~cm}$ dia.) nested quadrate of size $10 \mathrm{~m} \times 10 \mathrm{~m}$ for poles (10-29.9 $\mathrm{cm}$ dia.), $5 \mathrm{~m} \times 5 \mathrm{~m}$ for sapling ( $>5 \mathrm{~cm} \mathrm{dia.)}$ and $1 \mathrm{~m} \times 1 \mathrm{~m}$ for regeneration, grass and herb were laid out at different aspects for collecting biomass. Tree species whose height was less than $1 \mathrm{~m}$ and diameter less than $5 \mathrm{~cm}$ were considered as shrub (Shrestha and Singh [5]).

\subsubsection{Biophysical measurements}

Diameter at breast height of each tree within the plot was measured using a diameter tape and the height of each tree was estimated using a Sunto clinometer and Abney's level. For woody shrubs, the diameter was measured at $15 \mathrm{~cm}$ aboveground level. All under storey bushes, grasses and herbaceous plants were clipped and the fresh weight of the samples were determined and a representative sub-sample of $300 \mathrm{gm}$ was taken to the laboratory to be oven dried.

\subsubsection{Soil sampling}

Four profiles from each forest types were dug at the center part of the plot up to $1 \mathrm{~m}$ depth for deep soils and up to bed rock for shallow soils. Soil samples at different depths $(0-20 \mathrm{~cm}, 20-40 \mathrm{~cm}, 40-60 \mathrm{~cm}, 60-80 \mathrm{~cm}$, and $80-100 \mathrm{~cm})$ were taken. A core ring sampler of $9.5 \mathrm{~cm}$ long with $4.2 \mathrm{~cm}$ diameter was used for bulk density. The soil samples were air-dried in the shade, and ground manually passed through a $2-\mathrm{mm}$ sieve. All the soil samples were analyzed in the laboratory.

\subsection{Data analysis}

\subsubsection{Biomass estimation}

The biomass of tree includes all parts such as stems, branches, twigs, leaves and roots. 
2.3.1.1 Aboveground biomass estimation The total stem volume of each tree was calculated using the relationship developed by Sharma and Pukkala [6].

$$
\ln (\mathrm{V})=\mathrm{a}+\mathrm{b} * \ln (\mathrm{d})+\mathrm{c} * \ln (\mathrm{h})
$$

where $\mathrm{V}=$ the total stem volume with bark, $\mathrm{d}=$ the diameter at breast height $(\mathrm{cm}), \mathrm{h}=$ the tree height $(\mathrm{m})$, and $\mathrm{a}, \mathrm{b}$, and $\mathrm{c}$ are species specific constants shown in table 1 .

Table 1: $\quad$ Parameters $a, b$, and $c$ for major tree species.

\begin{tabular}{|c|c|c|c|c|c|}
\hline SN & Species & $\mathrm{a}$ & $\mathrm{b}$ & $\mathrm{C}$ & $\mathrm{R}^{2}$ \\
\hline 1 & Shorea forest & -2.4545 & 1.9026 & 0.8352 & 98.3 \\
\hline 2 & Pine-Shorea forest & -2.9770 & 1.9235 & 1.0019 & 99.2 \\
\hline 3 & Schima-Castanopsis forest & -2.7285 & 1.8155 & 1.0072 & 98.3 \\
\hline 4 & Miscellaneous spp in hill forest & -2.3204 & 1.8507 & 0.8223 & 97.7 \\
\hline
\end{tabular}

After calculating the volume of the tree, it was multiplied by the density of the wood (Chaturvedi and Khanna [7]) of the species to get the aboveground biomass (dry weight stem biomass). The biomass of branches and leaves were estimated using $45 \%$ and $11 \%$ of the stem biomass respectively (Sharma [8]).

2.3.1.2 Under-growth biomass Regeneration/under-storey bushes, grasses and herbaceous layers were clipped and weighed. Representative samples of undergrowth of about 200 grams were taken, dried at room temperature, recording its weight and oven dried for 72 hours at $75^{\circ} \mathrm{C}$. Oven dry biomass values for litter, under storey bushes and grasses were calculated using the following formula by Lasco et al. [9]:

$$
\mathrm{ODW}=\frac{\mathrm{TFW}-(\mathrm{TFW} *(\mathrm{SFW}-\mathrm{SODW}))}{\mathrm{SFW}}
$$

where ODW $=$ Total oven dry weight, TFW $=$ Total fresh weight, SFW = Sample fresh weight, SODW = Sample oven dry weight

The biomass of woody perennial shrubs was calculated using the equation developed by Hasse and Hasse [10]:

$$
\mathrm{Y}=\mathrm{a} \mathrm{D}^{\mathrm{b}}
$$

where $\mathrm{Y}$ is the total dry biomass $(\mathrm{kg}), \mathrm{D}$ is the diameter $15 \mathrm{~cm}$ above the ground $(\mathrm{cm}), \mathrm{a}$, and b are constants whose values were considered as -4.264 and 1.016 respectively, and with a correction factor of 1.0232 (Hasse and Hasse [10]).

2.3.1.3 Belowground biomass estimation The root biomass of trees varies according to species, age, microclimate and soil. For this study the following relationships were used for estimating the root biomass (FAO [11]). 
For coniferous vegetation:

belowground biomass $=0.25 \mathrm{x}$ aboveground biomass.

For broadleaf vegetation:

belowground biomass $=0.30 \mathrm{x}$ aboveground biomass.

\subsubsection{Estimation of net carbon content}

The aboveground tree carbon (stem, branch and leaf carbon) and root carbon were calculated using the stock method. The total carbon was assumed to be $43 \%$ of the biomass. Total $10 \mathrm{gm}$ ( 8 gm stem with bark +2 gm leaf) of oven dried undergrowth was burnt in an electrical furnace at $400^{\circ} \mathrm{C}$ for 30 minutes, ash content (inorganic elements in the form of oxides) left after burning was weighed, carbon \% of undergrowth and leaf litter was determined by the ash content method (Negi et al. [12]). The following formulae were used for computing the total above and belowground biomass organic carbon.

Total aboveground biomass organic carbon

$=($ total aboveground biomass of tree + total branch and litter biomass

+ total under storey biomass + shrub biomass) $* 43 \%$

and

Total belowground biomass organic carbon

$=(\text { total root biomass of tree })^{*} 43 \%+$ total soil organic carbon.

\subsubsection{Soil organic carbon (SOC)}

Collected soil samples were analyzed in the soil laboratory and the soil organic $\mathrm{C}$ percentage was calculated (Negi et al. [12]).

$$
\begin{aligned}
\text { Carbon } \%= & 100-(\text { Ash weight }+ \text { molecular weight } \\
& \text { of } \left.\mathrm{O}_{2}(53.3) \text { in } \mathrm{C}_{6} \mathrm{H}_{12} \mathrm{O}_{6}\right)
\end{aligned}
$$

The formulae used for determining above and belowground biomass organic carbon were:

Total aboveground biomass organic carbon

$=($ total aboveground biomass of the tree $\mathrm{x} 43 \%$

+ Undergrowth biomass x Carbon \% + litter biomass x Carbon \%)

Total belowground biomass organic carbon

$=($ total root biomass of tree $) \times 43 \%+$ total soil organic carbon $)$

The Walkey-Black method was applied for measuring the soil organic carbon (McLean [13]). The total soil organic carbon was calculated using the formula given below (Awasthi et al. [14]):

SOC $\left(\mathrm{kg} / \mathrm{m}^{3}\right)=$ Organic Carbon Content $\%$

$\mathrm{x}$ soil bulk density $\left(\mathrm{kg} / \mathrm{m}^{3}\right) \mathrm{x}$ thickness of horizon $(\mathrm{m})$.

Further, the soil organic carbon was expressed in tons per hectare. 


\subsubsection{Bulk density}

Soil bulk density was determined using the core sampling method (Blake and Hartge [15]). The oven dry weight of soil samples will be determined for moisture correction. The dried soil was then passed through a $2 \mathrm{~mm}$ sieve, the sieved soil was weighed and the volume of stones was recorded for stone correction. The following formula was used to calculate the bulk density using stone correction (Pearson et al. [16]).

$$
\begin{aligned}
& \text { Bulk density }\left(\mathrm{g} / \mathrm{cm}^{3}\right)=\quad \text { Ovendry mass }\left(\mathrm{g} / \mathrm{cm}^{3}\right) \\
& \text { Core volume }\left(\mathrm{cm}^{3}\right) \text { - Mass of coarse fragments }(\mathrm{g}) \\
& \text { Density of rock fragment }\left(\mathrm{g} / \mathrm{cm}^{3}\right)
\end{aligned}
$$

where, the coarse fragments are $>2 \mathrm{~mm}$. The density of rock fragments is $2.65 \mathrm{~g} / \mathrm{cm}^{3}$.

Statistical analysis was carried out using SPSS and simple modeling using MS Excel while preparing the database. The least significant difference (LSD) was used for multiple comparisons of means. The variability in soil and biomass carbon was measured in terms of range, standard error of means (SE) and analysis of variance (ANOVA).

\section{Result and discussion}

\subsection{Properties of forest stand}

Biomass and biomass carbon sequestration mainly depends on density and size of the stand. The mean diameter $(22.12 \mathrm{~cm})$ in a Pine-Shorea forest followed by degraded forest $(17.11 \mathrm{~cm})$ and Shorea forest $(16.78 \mathrm{~cm})$ and found least in a Schima-Castanopsis forest $(14.48 \mathrm{~cm})$. Similarly a Shorea forest stand has more trees (1338 trees/ha), a Schima-Castanopsis forest (904 trees/ha), a Pine-Shorea forest (730 trees/ha) and degraded forest (480 trees/ha).

\subsection{Aboveground biomass estimation}

The biomass of tree and underground vegetation varies with forest types, age of the stand, density of vegetation, species, aspect and elevation. Aboveground tree biomass was higher $\left(170.95 \pm 23.03\right.$ ton $\left.^{-1} \mathrm{a}^{-1}\right)$ in dense Shorea forest (S) (table 2) followed by Pine-Shorea forest (PS) $\left(128.96 \pm 31.27\right.$ ton ha $\left.{ }^{-1}\right)$ (table 2) and Schima-Castonopsis forest (SC) $\left(91.3 \pm 13.56\right.$ ton ha $\left.^{-1}\right)$ (table 2) and was found lower $\left(63.82 \pm 27.81\right.$ ton $\left.\mathrm{ha}^{-1}\right)$ in degraded forest (DF) (table 2). Undergrowth biomass was higher $\left(5.73 \pm 1.2\right.$ ton $^{-1} \mathrm{ha}^{-1}$ in the Shorea forest (table 2) followed by the Schima-Castnopsis forest $\left(3.07 \pm 1.32\right.$ ton $\mathrm{ha}^{-1}$ ) (table 2) and was found lower $\left(0.76 \pm 0.43\right.$ ton $\left.\mathrm{ha}^{-1}\right)$ in the degraded forest (table 2$)$. Undergrowth biomass was in order of DS $>$ SC $>$ PS $>$ DF. The leaf litter biomass was found higher $\left(1.6 \pm 0.66\right.$ ton $\left.\mathrm{ha}^{-1}\right)$ in the PS forest (table 2) and lower $(0.32 \pm 0.1$ ton $\mathrm{ha}^{-1}$ ) in the DF (table 2). It was in order of PS $>\mathrm{SC}>\mathrm{DS}>\mathrm{DF}$.

The result showed that total aboveground biomass was higher (177.64 \pm 23.43 ton $\mathrm{ha}^{-1}$ ) in the $\mathrm{S}$ forest (table 2). It is due to a higher density of vegetation in the $\mathrm{S}$ forest in comparison to other forest types. The total aboveground 
biomass of the PS forest was found in the second position $(132.82 \pm 31.66$ $177.64 \pm 23.43$ ton $\mathrm{ha}^{-1}$ ) (table 2) followed by the SC forest, found in second position $\left(95.47 \pm 14.21\right.$ ton $\left.\mathrm{ha}^{-1}\right)$ (table 2$)$. It is because larger and matured trees of pine species were found in the PS forest in comparison to other forest types. The total aboveground biomass was lower $\left(65.00+27.65\right.$ ton $\left.\mathrm{ha}^{-1}\right)$ in the degraded forest (table 2). Similar results were found in Lalitpur and Palpa districts, Nepal. Karki [17] reported that the aboveground tree biomass of the Schima-Castonopsis forest in Kafle CF forest in Lalitpur was 91.76 ton $\mathrm{ha}^{-1}$. Shrestha [18] reported an aboveground tree biomass of Shorea forest in Bharkes CF in Palpa district was 177.24 ton $\mathrm{ha}^{-1}$.

Table 2: $\quad$ Total aboveground biomass (ton $\left.\mathrm{ha}^{-1}\right)$ in different forest types.

\begin{tabular}{|c|c|c|c|c|c|}
\hline $\begin{array}{c}\text { Forest } \\
\text { Types }\end{array}$ & $\begin{array}{l}\text { Types of } \\
\text { Biomass }\end{array}$ & $\begin{array}{l}\text { Biomass } \\
\left.\left(\text { ton }^{-1}\right)^{-1}\right)\end{array}$ & $\operatorname{Min}^{\mathrm{m}}$ & $\operatorname{Max}^{\mathrm{m}}$ & S Error \\
\hline \multirow[t]{3}{*}{ Shorea forest } & Tree Biomass & 170.95 & 66.12 & 338.15 & 23.03 \\
\hline & Leaf litter Biomass & 1.06 & 0.07 & 2.23 & 0.19 \\
\hline & Undergrowth Biomass & 5.73 & 0.54 & 17.28 & 1.2 \\
\hline \multicolumn{2}{|c|}{ Total Aboveground Biomass } & 177.74 & 66.73 & 357.64 & 24.42 \\
\hline \multirow{3}{*}{$\begin{array}{c}\text { Pine-Shorea } \\
\text { forest }\end{array}$} & Tree Biomass & 128.96 & 25.55 & 190.73 & 31.27 \\
\hline & Leaf litter Biomass & 1.6 & 0.37 & 3.77 & 0.66 \\
\hline & Undergrowth Biomass & 2.26 & 0.53 & 6.90 & 1.34 \\
\hline \multicolumn{2}{|c|}{ Total Aboveground Biomass } & 132.82 & 26.45 & 201.40 & 33.27 \\
\hline \multirow{3}{*}{$\begin{array}{c}\text { Schima- } \\
\text { Castonopsis } \\
\text { forest }\end{array}$} & Tree Biomass & 91.3 & 51.44 & 138.15 & 13.56 \\
\hline & Leaf litter Biomass & 1.1 & 0.37 & 3.77 & 0.25 \\
\hline & Undergrowth Biomass & 3.07 & 0.53 & 6.90 & 1.32 \\
\hline \multicolumn{2}{|c|}{ Total Aboveground Biomass } & 95.47 & 52.34 & 148.82 & 15.13 \\
\hline \multirow{3}{*}{$\begin{array}{l}\text { Degraded } \\
\text { forest }\end{array}$} & Tree Biomass & 63.82 & 14.28 & 181.14 & 27.81 \\
\hline & Leaf litter Biomass & 0.32 & 0.07 & 0.74 & 0.10 \\
\hline & Undergrowth Biomass & 0.76 & 0.05 & 2.70 & 0.43 \\
\hline \multicolumn{2}{|c|}{ Total Aboveground Biomass } & 64.90 & 14.40 & 814.58 & 28.34 \\
\hline
\end{tabular}

\subsection{Aboveground carbon stock}

\subsubsection{Carbon content in undergrowth and leaf litter}

Carbon content ( $\%$ carbon) of the biomass varies on species, component of biomass (leaf, bark, stem, root, leaf litter). The carbon content of undergrowth and leaf litter are shown in table 3 . The carbon content of undergrowth was found maximum (44.63\%) in a Pine-Shorea forest and minimum $(43.67 \%)$ in a Schima-Castonopsis forest, while the carbon content of leaf litter was found maximum $(44.46 \%)$ in a Shorea forest and minimum $(43.17 \%)$ in a SchimaCastonopsis forest. Negi et al. [12] observed that the maximum carbon is stored in the order of coniferous $>$ deciduous $>$ evergreen $>$ bamboo and he found $44.07 \%, 43.46 \%$, and $46.11 \%$ carbon in bark, leaf, and wood biomass of a pinus ruxburghii forest respectively and $41.72 \%, 42.58 \%$, and $45.46 \%$ carbon in bark, leaf, and wood biomass of a shorea robusta forest respectively. 
Table 3: Carbon content in under-growth and leaf litter.

\begin{tabular}{|c|c|c|c|c|c|c|c|c|}
\hline \multirow{2}{*}{ Forest Types } & \multicolumn{4}{|c|}{ Undergrowth Carbon \% } & \multicolumn{4}{c|}{ Leaf Litter Carbon \% } \\
\cline { 2 - 9 } & Mean & Min & Max & SE & Mean & Min & Max & SE \\
\hline Shorea & 44.00 & 43.91 & 44.09 & 0.03 & 44.44 & 44.25 & 44.60 & 0.07 \\
\hline Pine-Shorea & 44.61 & 44.30 & 45.00 & 0.13 & 43.86 & 43.75 & 44.00 & 0.06 \\
\hline $\begin{array}{c}\text { Schima- } \\
\text { Castonopsis }\end{array}$ & 43.64 & 43.45 & 43.83 & 0.08 & 43.21 & 42.59 & 43.76 & 0.21 \\
\hline Degraded & 44.33 & 44.25 & 44.41 & 0.03 & 43.47 & 43.20 & 43.80 & 0.11 \\
\hline
\end{tabular}

\subsubsection{Total aboveground carbon stock}

The photosynthesis process carbon from the atmospheric $\mathrm{CO}_{2}$ includes products of organic compounds. All the organic compounds containing carbon are stored in different plant tissues as food. Thus, carbon appears as a part of the plant biomass. The total aboveground organic carbon includes carbon on the aboveground tree biomass (e.g., branch, stem, leaves), litter fall, twigs and biomass of undergrowth (Gautam [19]).

\subsection{Belowground biomass and carbon stock}

Belowground biomass (root) was found higher $\left(52.97\right.$ ton ha $\left.^{-1}\right)$ in a Shorea forest (S) followed by Pine-Shorea forest (PS) (35.10 ton ha $\left.{ }^{-1}\right)$. Root biomass of Schima-Castonopsis forest (SC) and degraded forest (DF) was 28.31 ton ha $^{-1}$ and 19.37 ton $\mathrm{ha}^{-1}$ respectively. Obviously carbon sequestration from root was in order of S > PS $>$ SC $>$ DF and carbon stock was $22.78+3.02$ ton ha $^{-1}, 15.09+$ 3.04 ton ha ${ }^{-1}, 12.17+1.83 \mathrm{t} /$ ha $^{-1}$ and $8.32+3.57$ ton ha-1 respectively (table 4 ).

Table 4: $\quad$ Belowground biomass carbon (in tons per hectare).

\begin{tabular}{|c|c|c|c|c|c|}
\hline Forest Types & Root Biomass & Root Carbon & $\operatorname{Min}^{\mathrm{m}}$ & $\mathrm{Max}^{\mathrm{m}}$ & $\mathrm{SE}$ \\
\hline $\begin{array}{c}\text { Shorea forest } \\
\text { Pine-Shorea forest }\end{array}$ & 35.10 & 22.78 & 8.88 & 43.97 & 3.02 \\
\hline $\begin{array}{c}\text { Schima- } \\
\text { Castonopsis }\end{array}$ & 28.31 & 15.09 & 2.81 & 211.80 & 3.04 \\
\hline Degraded forest & 19.37 & 8.32 & 7.09 & 18.23 & 1.83 \\
\hline
\end{tabular}

The carbon stock in forest vegetation varies according to geographical location, plant species, and age of the stand (Van Noordwijk et al. [20]).

\subsection{Soil carbon sequestration}

\subsubsection{Bulk density}

Great variation was found in bulk density in all types of forests in different soil profiles. A gradual increase in bulk density was seen with the increase in depth in each forest type. A significant difference in bulk density was seen at depth $(0-$ $20 \mathrm{~cm}),(20-40 \mathrm{~cm}),(40-60 \mathrm{~cm}),(60-80 \mathrm{~cm})$ and $(80-100 \mathrm{~cm})$ within the forest type as well as in all other forest types. Bulk density increases as we go deeper 
and deeper due to natural compaction of soil (table 5). Bulk density depends on several factors such as compaction, consolidation and the amount of SOC present in the soil but it is highly correlated to the organic carbon content (Morisada et al. [21]; Leifeld et al. [22]). Bulk density of top humus soil layer was found 1.25 (ton $\mathrm{m}^{-1}$ ) in the forest of the same study area at the depth of 0 $20 \mathrm{~cm}$ irrespective of forest types (Tiwari et al. [23]). Bulk density was slightly higher in a degraded forest than other forest types, as a degraded forest has an open space due to heavy grazing and trampling of soil by livestock as well as movement of people. The soil type was observed to also be of low permeability due to the high clay lateritic type of red soil.

Table 5: $\quad$ Bulk density (tons $\mathrm{m}^{-3}$ ) in different forest types.

\begin{tabular}{|c|c|c|c|c|c|}
\hline $\begin{array}{l}\text { Forest } \\
\text { Types }\end{array}$ & Soil Depth $(\mathrm{cm})$ & Bulk Density tons $\mathrm{m}^{-3}$ & $\operatorname{Min}^{m}$ & $\operatorname{Max}^{\mathrm{m}}$ & SE \\
\hline \multirow{5}{*}{$\begin{array}{l}\text { Shorea } \\
\text { forest }\end{array}$} & $0-20$ & 1.20 & 0.95 & 1.44 & 0.09 \\
\hline & $20-40$ & 1.36 & 1.21 & 1.41 & 0.06 \\
\hline & $40-60$ & 1.40 & 1.07 & 1.55 & 0.09 \\
\hline & $06-80$ & 1.45 & 1.16 & 1.65 & 0.09 \\
\hline & $80-100$ & 1.47 & 1.40 & 1.60 & 0.07 \\
\hline \multirow{5}{*}{$\begin{array}{l}\text { Pine-Shorea } \\
\text { forest }\end{array}$} & $0-20$ & 1.27 & 1.00 & 1.43 & 0.08 \\
\hline & $20-40$ & 1.38 & 1.19 & 1.49 & 0.06 \\
\hline & $40-60$ & 1.44 & 1.26 & 1.58 & 0.06 \\
\hline & $06-80$ & 1.47 & 1.09 & 1.62 & 0.11 \\
\hline & $80-100$ & 1.52 & 1.10 & 1.77 & 0.14 \\
\hline \multirow{5}{*}{$\begin{array}{l}\text { Schima- } \\
\text { Castonopsis } \\
\text { forest }\end{array}$} & $0-20$ & 1.17 & 1.08 & 1.33 & 0.05 \\
\hline & $20-40$ & 1.22 & 1.09 & 1.42 & 0.07 \\
\hline & $40-60$ & 1.27 & 1.06 & 1.51 & 0.08 \\
\hline & $06-80$ & 1.30 & 1.26 & 1.33 & 0.01 \\
\hline & $80-100$ & 1.32 & 1.26 & 1.39 & 0.02 \\
\hline \multirow{5}{*}{$\begin{array}{l}\text { Degraded } \\
\text { forest }\end{array}$} & $0-20$ & 1.40 & 1.39 & 1.42 & 0.01 \\
\hline & $20-40$ & 1.43 & 1.27 & 1.74 & 0.09 \\
\hline & $40-60$ & 1.46 & 1.28 & 1.75 & 0.09 \\
\hline & 06-80 & 1.46 & 1.25 & 1.70 & 0.09 \\
\hline & $80-100$ & 1.49 & 1.34 & 1.72 & 0.08 \\
\hline
\end{tabular}

\subsubsection{Soil organic carbon}

Organic carbon was found higher at the upper level of soil in almost all cases. In a Schima-Castonopsis forest OCC was higher than other types of forest (table 6). The greater the depth, the lower the OCC in all forest types. 
Table 6: $\quad$ Organic carbon content (OCC \%) in different types of forest.

\begin{tabular}{|c|c|c|c|c|}
\hline \multirow{2}{*}{$\begin{array}{c}\text { Soil Depth } \\
(\mathrm{cm})\end{array}$} & \multicolumn{3}{|c|}{ Organic carbon content (OCC \%) in different forest types } \\
\cline { 2 - 5 } & $\begin{array}{c}\text { Shorea } \\
\text { forest }\end{array}$ & $\begin{array}{c}\text { Pine-Shorea } \\
\text { forest }\end{array}$ & $\begin{array}{c}\text { Schima- } \\
\text { Castonopsis forest }\end{array}$ & $\begin{array}{c}\text { Degraded } \\
\text { forest }\end{array}$ \\
\hline $0-20$ & 0.94 & 0.76 & 2.33 & 0.58 \\
\hline $20-40$ & 0.39 & 0.41 & 0.61 & 0.21 \\
\hline $40-60$ & 0.24 & 0.19 & 0.35 & 0.21 \\
\hline $60-80$ & 0.20 & 0.17 & 0.28 & 0.20 \\
\hline $80-100$ & 0.26 & 0.11 & 0.21 & 0.16 \\
\hline
\end{tabular}

Table 7: $\quad$ Total carbon stock in different types of forest.

\begin{tabular}{|c|c|c|c|c|}
\hline $\begin{array}{c}\text { Type of } \\
\text { Forest }\end{array}$ & Carbon Source & $\begin{array}{c}\text { Carbon stock } \\
\text { tons / ha }\end{array}$ & $\begin{array}{c}\text { Forest Area } \\
\text { in ha }\end{array}$ & $\begin{array}{c}\text { Carbon stock in } \\
\text { watershed (in ton) }\end{array}$ \\
\hline Shorea forest & Aboveground & 76.50 & 174 & 13311.00 \\
\cline { 2 - 5 } & Root carbon & 22.78 & 174 & 3963.72 \\
\cline { 2 - 5 } & Soil carbon & 51.54 & 174 & 8967.96 \\
\cline { 2 - 5 } & Total & 150.82 & & 26242.68 \\
\hline \multirow{4}{*}{$\begin{array}{c}\text { Pine-Shorea } \\
\text { forest }\end{array}$} & Aboveground & 41.07 & 76 & 3121.32 \\
\cline { 2 - 5 } & Root carbon & 12.17 & 76 & 924.92 \\
\cline { 2 - 5 } & Soil carbon & 88.54 & 76 & 6729.04 \\
\cline { 2 - 5 } & Total & 141.78 & & 10775.28 \\
\hline \multirow{3}{*}{$\begin{array}{c}\text { Schima- } \\
\text { forest }\end{array}$} & Aboveground & 57.63 & 20 & 1152.60 \\
\cline { 2 - 5 } & Root carbon & 15.09 & 20 & 301.80 \\
\cline { 2 - 5 } & Soil carbon & 43.94 & 20 & 878.80 \\
\cline { 2 - 5 } & Total & 116.66 & & 2333.20 \\
\hline \multirow{2}{*}{$\begin{array}{c}\text { Degraded } \\
\text { forest }\end{array}$} & Aboveground & 27.92 & 42 & 1172.64 \\
\cline { 2 - 5 } & Root carbon & 8.32 & 42 & 349.44 \\
\cline { 2 - 5 } & Soil carbon & 39.29 & 42 & 1650.18 \\
\cline { 2 - 5 } & Total & 75.53 & & 3172.26 \\
\hline
\end{tabular}

\subsection{Total carbon stock}

The sum of carbon in aboveground biomass, root, and soil is the total carbon stock (table 8).

Table 8: $\quad$ Total carbon stock in different forest types.

\begin{tabular}{|c|c|c|c|c|}
\hline Forest Types & Forest Area & $\%$ Area Cover & CS in ton & CS in \% \\
\hline Shorea forest & 174 & 55.77 & 26242.68 & 61.71 \\
\hline $\begin{array}{c}\text { Pine-Shorea } \\
\text { forest }\end{array}$ & 20 & 6.41 & 2333.20 & 5.49 \\
\hline $\begin{array}{c}\text { Schima-Castonopsis } \\
\text { forest }\end{array}$ & 76 & 24.36 & 10775.28 & 25.34 \\
\hline Degraded forest & 42 & 13.46 & 3172.26 & 7.46 \\
\hline Total & 312 & $100 \%$ & 42523.42 & $100 \%$ \\
\hline
\end{tabular}




\section{Conclusions}

The total biomass carbon in forests was found to be 77.68 ton $\mathrm{ha}^{-1}$. Similarly, soil organic carbon sequestration was found to be 58.6 ton $\mathrm{ha}^{-1}$. The highest biomass carbon was found in a Shorea forest followed by a Pine-Shorea forest. The highest SOC was found in a Schima-Castonopsis forest followed by a Shorea forest. Total carbon sequestration was highest in a Shorea forest, which was in order of Shorea forest $(61.72 \%)>$ Schima-Castonopsis forest $(25.33 \%)>$ PineShorea forest $(5.49 \%)>$ degraded forest $(7.46 \%)$. Thus, total carbon sequestration by all forest types was 42523 ton $\mathrm{ha}^{-1}$.

\section{Acknowledgements}

I am thankful to IoF-NUFU Networking (HIMUNET) Project, Pokhara for financial support. I like to express my thanks to Prof. Mohan K. Balla, Ram Kumar Bhandari, Narayan Shrestha, Bishnu Giri, and for their help during my field work.

\section{References}

[1] Sedjo, R.A., Sohngen, B. and Jagger, P. Carbon sinks in the post-Kyoto world, Resources for the Future. Sequestering of carbon in tropical and subtropical soils. Ambio 22. pp 417-426, 1998. USA.

[2] Brown, K. and Pearcel, D. The economic value of non-timber benefits of tropical forests: Carbon storage. In Weiss, J. (Ed.) The economics of project appraisal and the environment: New horizons in environment economics. Cheltenham (UK), 1994.

[3] Hamburg, S.P. Simple rules in measuring change in ecosystem carbon in forestry offset project. Mitigation, Adaptation Strategy Global Change (1): 25-37, 2000.

[4] IPCC. The Intergovernmental Panel on Climate Change, special report on land use, land-use change and forestry. Cambridge University Press, Cambridge, UK, 2000.

[5] Shrestha, B.M. and Singh, B.R. Soil and vegetation carbon pools in a mountainous watershed of Nepal. Nutrient Cycling in Agro ecosystems 81:179-191 (DOI 10.1007/s10705-007-9148-9) 2008.

[6] Sharma, R.P. and Pukkala, J. Volume tables for forest trees of Nepal, 48, Ministry of Forest, Survey and Statistics Division, Kathmandu, Nepal. pp 84, 1990.

[7] Chaturvedi A.N. and L.S. Khanna,. Forest mensuration. International Book Distributors, Dehradun, India, pp 408, 1982.

[8] Sharma, R.P. Relationship between tree dimensions and biomass, sapwood area, leaf area and leaf area index in Alnus nepalensis, D. Don in Nepal, Agricultural University of Norway (NLH) 2003.

[9] Lasco, R.D., Pulhin, F.B., Cruz, R.V.O., Pulhin, J.M., Roy, S.S.N., 2005. Carbon budgets of terrestrial ecosystems in the Pantabangan-Carranglan 
watershed. Assessment of impacts and adaptations to climate change (AIACC) working paper. www.aiaccproject.org

[10] Hasse, R. and Hasse, P. Aboveground biomass estimates for invasive trees and shrubs in the Pantanal of Mato-Grosso, Brazil for Ecological Management 73(1-3): 29-35, 1995.

[11] FAO. Carbon sequestration option under the clean development mechanism to address land degradation. FAO forestry paper 47, 2000. Rome, Food and Agricultural Organization.

[12] Negi, J.D.S., Manhas, R.K., Chauhan, P.S. Carbon allocation in different components of some tree species of India: A new approach for carbon estimation. Curr Sci India 85(11): 1528-1531, 2003.

[13] McLean, E. O. Soil pH and lime requirement. In: Page, A.L., Miller, R.M., Keeney, D.R. (eds.) Methods of soil analysis part 2. Chemical and microbiological properties, 2nd edition. American Society of Agronomy Monograph No. 9, ASA-SSSA, Inc., Madison, WI, USA. pp 199-224, 1982.

[14] Awasthi, K.D., Singh, B.R., Sitaula, B.K. Profile carbon and nutrient levels and management effect on soil quality indicators in the Mardi watershed of Nepal. Acta agriculture Scandenevia Section B - Soil and Plant, 55: 192-204, 2005.

[15] Blake, G.R. and Hartge, K.H. Bulk density. In: pp 363-375, 1986. A. Klute, (ed.) Methods of soil analysis part 1. Physical and mineralogical methodsagronomy monograph 2nd edition. Book No. 5. American Society of Agronomy-Soil Science Society of America (ASA-SSSA). Madison. WI.

[16] Pearson, T.R.H., Brown, S., Ravindranath, N.H., 2005. Integrating carbon benefit estimates into GEF projects. Capacity development and adaptation group guidelines. United National Development Policy, New York, USA.

[17] Karki, B.S., Kafle community forest, Lamatar, Nepal community forest management as a carbon mitigation option, pp. 8-14, 2006.

[18] Shrestha, B.P. An analytical study of carbon sequestration in three different forest types of mid-hills of Nepal. M. Sc. Thesis, IoF, Pokhara, Nepal, 2009.

[19] Gautam, K.R. Carbon sequestration in Agro-forestry and annual cropping system in inner Terai, Central Nepal. M.Sc. thesis submitted to Agricultural University of Norway (NLH) 2002.

[20] Van Noordwijk M., C. Cerri, P.L. Woomer, K. Nugroho and M. Bernoux.

Soil carbon dynamics in the humid tropical forest zone. Geoderma 79 (1-4): 187-225, 1997.

[21] Morisada, K.: K. Ono and H. Kanomata. Organic carbon stock in forest soils in Japan, Geoderma 119, pp 21-32, 2004.

[22] Leifeld, J. Bassin and B.A. Stewart, 2004. Carbon stock in Swiss agriculture soils predicted by land use soil characteristics, and altitude, agriculture, Ecosystem and Environment.

[23] Tiwari, K. R., B.K. Sitaula, T. Borresen and R.M. Bajracharya. An assessment of soil quality in Pokhare khola watershed of the middle mountain in Nepal. Journal of food, agriculture and environment Vol. 4 (3 \& 4): 276-283, 2006. 